\title{
Knowledge management and digital business transformation
}

\author{
Vanja Erceg \\ Faculty of Economics in Subotica, University of Novi Sad, Subotica, Serbia \\ https://orcid.org/0000-0002-7451-6216
}

Tihomir Zoranović

Faculty of Agriculture, University of Novi Sad, Novi Sad, Serbia

https://orcid.org/0000-0003-2564-5000

\begin{abstract}
The fourth industrial revolution is in progress, and the center of this revolution is the digital transformation. Companies need to keep up with new business models and advances in digital technologies so that they can agilely adapt to changes in the market. Also, organizations should become aware of the growing importance of knowledge management, as well as the skills needed to make business decisions. Research related to knowledge management is becoming more complex, which indicates the multi-disciplinarity of this area and its close connection with digital technologies and digital transformation. The aim of this paper is to try to explain the importance of knowledge management in organizations and where it fits into the digital business transformation. For the purpose of this paper, a standard methodology of the systematic literature review was used. The paper provides an overview of the current scientific cognition of knowledge management and knowledge management systems and analyzes the relationship between knowledge management and digital transformation.
\end{abstract}

\section{Keywords}

Knowledge management, knowledge management systems, digital transformation, organizational culture.

\section{Introduction}

In order to gain or increase market share in the digital age, companies must act quickly when a new business opportunity arises. This means that companies need information technology (IT) solutions immediately. To achieve this, staff employed in companies must be qualified and able to use modern technologies, which can drive process automation. Business and IT functions need to find ways to improve knowledge exchange because knowledge management has strategic importance for maintaining a competitive position in the market.

According to Markić (2016), knowledge management is, in the scientific sense, the concept of organizing, extracting, distributing and using knowledge within the organization, while in the applied sense it represents the business practice and applied technologies. The goal of knowledge management is to provide the necessary knowledge to make business decisions. This means that the necessary knowledge should be available to the right people at the right time and used to improve business efficiency, in order to establish innovations that enable development (Vukotić, Zakić \& Ćurčić, 2017). Knowledge management implies a constant process of knowledge renewal in the organization and consists of several phases: knowledge collection, knowledge storage, knowledge distribution, and application of knowledge (Tešić, Marković, Plećić \& Pantelić, 2013).

Knowledge management has also been identified as one of three pillars of digital transformation, in addition to infrastructure 
management and API management (Mcinerney \& Koenig, 2011). Other authors support a similar point of view which emphasizes the main points for the realization of digital transformation and those are digital strategy, effective integration strategy in business process, knowledge management, an adaptation of organizational culture, and integration of digital technologies in business (Schumann \& Tittmann, 2015). From the digital transformation perspective, knowledge management can be helpful in identifying and selecting the content of digitization (what needs to be digitalized) and adequate digital technologies that will give the best results during digital transformation. Digitalization and its integration in processes is an ongoing opportunity to develop appropriate knowledge management strategies, especially in the initial phase of digital transformation when organizational culture is more changeable than in the late stages. An adapted perspective of knowledge and continuous learning, which is tightly bonded with the change of organizational culture in the company, can help in the realization of digital transformations, which can result in achieving a higher level of market competitiveness, successful realization of business goals, better product development, improved customer orientation, etc. (Schumann \& Tittmann, 2015).

The efficiency of the knowledge management process hugely depends on the success of the application of modern information and communication technologies. Knowledge Management Systems (KMS) are excellent tools for sharing knowledge within an organization (Kaljević, 2016) and they are mostly grouped by the actions they perform, from searching the knowledge base to visualizing certain data (Mićić, 2016). KMS systems increase the ability of organizations to be more flexible and respond quickly to changing market conditions, as well as to be more innovative, productive, and make better business decisions (Alavi \& Leidner, 1999). The quality of knowledge management systems depends on features such as ease of use, characteristics of user interface, flexibility, and efficiency of search engines (Alavi \& Leidner, 2001). Although the concepts of knowledge management and KMS appeared at the end of last century, the emergence of modern digital technologies has opened up completely new possibilities when it comes to knowledge management.

But this is not only for knowledge management: it can be observed that modern business, in general, is characterized by an increasing reliance on digital technologies (Sofronijević, Milićević \& Ilić, 2017), such as Cloud Computing, Big Data, Internet of Things, Mobile, Social Media, and others. All these technologies use digitalized data to enhance business activities in organizations, effectively enabling digital business transformation. Integrating digital technologies into all areas of business requires relatively large financial investments. Therefore, it is necessary that the process of integration of these technologies is monitored from the beginning to the end, in order to achieve a positive result of digital transformation. The goal of digital transformation is to review current business models, implement digital technologies, initiate a change in organizational culture, and enable a more flexible response to changes. If organizations do not continuously work on the improvement of their business processes, the digital transformation will not give the desired results. Briefly, the process of digital transformation involves constantly discovering new ways to meet the growing needs of customers, which is greatly facilitated by knowledge management.

All of the above unequivocally indicates the existence of a deep connection and mutual influence between the digital business transformation and knowledge management, and their mutual relationship is the research subject of this paper.

\section{Research methodology}

For the purposes of the paper, the standard methodology of systematic review of the literature recommended by Brereton, Kitchenham, Budgen, Turner \& Khalil (2007), Kitchenham, Brereton, Budgen, Turner, Bailey \& Linkman (2009) and Kitchenham et al. (2010) was used. The systematic literature review protocol consists of the following steps:

\subsection{Defining research questions}

This paper discusses the following research question (RQ):

RQ: What is the relationship between knowledge management, digital transformation and cultural change in the organization?

RQ derives from the analysis of relevant literature to the given topic, in which it is noticeable that knowledge management is increasingly seen as a process necessary to maintain a competitive position in modern 
business, which also applies to the process of digital transformation. In this context, modern trends dictate the implementation of digital technologies in all aspects of business, including the knowledge management segment. By analyzing the process of digital transformation and the process of knowledge management, it is noticeable that cultural changes in the organization cannot be absent.

\subsection{Finding relevant researches}

Finding relevant literature for the topic of the paper was carried out manually in the following electronic libraries:

- Kobson (https://kobson.nb.rs/) and,

- Google Scholar (https://scholar.google.com/).

The papers were first selected based on keywords, then according to the title, then according to the abstract and finally according to the conclusion. The keywords that are used to search for papers are: knowledge management, knowledge management systems, digital transformation and organizational culture. The search for papers was performed based on keywords in English due to the relatively small number of available relevant papers in Serbian.

\subsection{Defining the criteria for inclusion and exclusion of studies}

The first criterion that the studies had to meet refers to the time period. Therefore, this research included those studies that were published in the period 2015-2020. The second criterion that the studies had to meet was that they were scientific, professional, or review papers published in a scientific journal or proceedings from conferences, books, or doctoral dissertations. In the first phase of the search based on keywords, 3,120 works were found. In the next step, papers that are considered relevant to the research topic were selected based on the title and there were 1,216 of them. The next criterion referred to the selection of papers based on abstracts and 139 studies were selected. According to Brereton et al. (2007), standard abstracts related to information technology and software engineering are not sufficient to conclude on their basis whether the study is relevant, and it is necessary to read the conclusions. Accordingly, after reading the conclusions, 35 relevant studies were selected.

\subsection{Qualitative evaluation}

Qualitative assessment of the relevance of selected papers was performed using criteria developed at York University, Center for Reviews and Dissemination (CDR) Database of Abstracts of Reviews of Effects (DARE), using Mendeley software.

\section{A review of the current standpoints in the literature}

In all aspects of modern life, access to quality information based on knowledge has become very important, so in the business world, knowledge is becoming one of the most important resources of the organization (Rašinovic, 2018). That approach has led to the development of a new concept called knowledge management, which has become a key factor in achieving a competitive advantage (Petrov, Ćelić, Uzelac, \& Drašković, 2020). In the past two decades, the concept of knowledge management, with a special focus on intellectual capital and modern technologies, has received growing attention. According to Jokanović, Tomić \& Duđak (2017), knowledge management emphasizes the importance of organizational culture, teamwork, learning, and exchange of knowledge, skills, and experiences. Jokanović et al. (2017) state that knowledge management consists of several phases, namely: creation, presentation, use, and transfer of knowledge. The creation and representation of knowledge refer to the way how knowledge appears in the minds of individuals. The utilization of knowledge refers to its use in decision making. Finally, knowledge transfer refers to the way an individual acquires and exchanges knowledge with other people. Since the efficiency of this process largely depends on the exchange of knowledge, this phase is the most important aspect of knowledge management (Petrov et al., 2020). According to Kaljević (2016) the basic sub-processes of knowledge management are knowledge creation, knowledge storage, knowledge sharing, and knowledge use. Knowledge sharing is crucial for organizations that want to use this resource to gain a competitive advantage. In this phase of knowledge management information technologies play a key role. An overview of the phases according to different authors is shown in Table 2.

Therefore, it is completely logical that the scientific literature on knowledge management emphasizes the importance of information technologies, because they facilitate the 
acquisition, storage, transfer and analysis of knowledge (Zbuchea \& Vidu, 2018). All this leads to the emergence of information systems intended for knowledge management. Knowledge management systems using different digital technologies and IT tools can play different roles in supporting knowledge management, but also in digital transformation.

Table 1 Overview of the phases of the knowledge management process according to the authors

\begin{tabular}{l|l|l|l|l}
\hline Authors & \multicolumn{4}{c}{ Phases } \\
\hline Tešić et al., 2013 & collecting & storage & distribution & application \\
\hline Kaljević, 2016 & creation & storage & sharing & usage \\
\hline Markić, 2016 & organizing & extracting & distributing & usage \\
\hline Jokanović et al., 2017 & creation & presentation & usage & transfer \\
\hline Zbuchea \& Vidu, 2018 & acquisition & storage & transfer & analysis \\
\hline
\end{tabular}

Studying the literature on knowledge management, it can be noticed that there is a difference between the concepts of knowledge sharing and knowledge transfer, as well as a review of barriers related to knowledge transfer (Paulin \& Suneson, 2011). Contradictions and discrepancies between the definitions of knowledge sharing and knowledge transfer can be found on several levels. Namely, while knowledge sharing takes place mainly between individuals, knowledge transfer takes place between individuals, teams, and organizations. Another difference relates to the fact that knowledge sharing can be focused or unfocused, but generally, there is no clearly defined goal in advance, while knowledge transfer must be clearly focused. Finally, knowledge sharing is considered a two-way process, as opposed to knowledge transfer which is seen as directed one-way communication. Regarding barriers related to knowledge transfer, they are often focused on the organizational culture that prevails in the company. Culture refers to the readiness and conditions under which an individual is willing to share knowledge with other members of the organization (Uzelac, Ćelić, Drašković, Berić \& Petrov, 2018). Also, according to (Pham, Phan, Tučková, Vo \& Nguyen, 2018), organizational culture has a positive effect on people's behavior towards the environment, which is one of the current topics today.

It is noticeable that there is a mutual conditionality between organizational culture and knowledge management. On the other hand, in order to be successful, digital transformation also requires a change in the culture of the organization. According to Halper (2019) in the modern business environment, it is necessary to change the culture and the way people work and cooperate with each other when using and exchanging data.
Optimization of knowledge flows in the organization, as an important determinant of knowledge management, implies efficient handling of information within the organization, which is today impossible to achieve without the strategic integration of multiple technologies. Knowledge management implies the application of collective knowledge of employees in order to achieve the company's business goals (Kaljević, 2016), but the efficiency of knowledge application is largely conditioned by the quality of information used in decision-making. All this clearly shows that information management is closely related to knowledge management (Nikolić, Vesić \& StošićMihajlović, 2017), where it can be freely stated that there is no efficient information management without digital business transformation.

The fact is that digital transformation involves the strategic integration of multiple technologies. However, despite the focus on digital technologies, the biggest demands placed on organizations are not technologies, but new ways of finding solutions for knowledge management. Technological change is forcing employees to find faster and more flexible ways of working and to acquire additional skills in order to manage the change. This is another proof that the change of organizational culture through the development of teams in charge of knowledge management is more important than the development of technological skills (APQC, 2019). Helmy, Abdelaal, Zaki, Ismail \& Khater (2018) state that further considerations are needed regarding the necessary changes in the organizational culture, which are pointed at adapting to work with new technologies, and not at imposing those technologies on employees.

It is commonly known that knowledge is a strategic resource for a company in the struggle to maintain a competitive advantage. With an increase of knowledge in an organization, the 
growth of knowledge contributes to the value of the company and improve its ability to respond to new challenges. For that reason, companies are increasingly investing in knowledge management and establishing knowledge management systems. The growing importance of knowledge has encouraged managers to focus more on knowledge management strategies to align organizational processes, culture, and IT implementation (Choi, Poon \& Davis, 2008). The knowledge management strategy takes place within a complex system that has a defined organizational structure and culture and is enabled through information technology. A successful knowledge management strategy identifies the key capabilities of the company to achieve business results. Often these opportunities are found in business processes that need to be transformed to take advantage of knowledge resources and expand the organization's capabilities (Melão \& Pidd, 2008).

According to Drechsler et al. (2020) knowledge management implies the optimal use of information and knowledge that an organization has at its disposal to improve its business, which is an integral part of digital transformation. This leads to the previously mentioned opinion that the process of knowledge management is one of the pillars of digital transformation. Kane (2019) states that companies must focus on three business problems if they want to effectively manage digital transformation, namely: navigation of digital disruptions, leadership review, and how to become a digital organization. Navigation of digital disruptions contains two terms at its core: digital disruption and digital transformation. Digital disruptions refer to the way in which digital technologies change business rules. On the other hand, the digital transformation speaks how companies are adapting to the new reality that has emerged as a result of digital disruption. Regarding the issue of leadership, the fact is that companies often don't recognize it, believing that all problems are solved by implementing new digital technology. Namely, it is relatively easy to implement new technology, and it is extremely difficult to change the way of doing business. There is only one way to a successful digital transformation, and that is through a change of culture. Some of the cultural characteristics that need to be changed are increasing agility, encouraging experiments, continuous learning, rewarding cooperation, accepting risks and developing functional teams (Kane, 2019).

\section{A brief overview of the authors' standpoints}

Reflecting on the standpoints of the authors, it can be concluded that knowledge management, digital transformation, and organizational culture are in a vicious circle of interdependence and mutual impact.

Organizational culture hugely influences the readiness and success of the organization in the adoption of knowledge management and digital transformation. Building (forming) an appropriate organizational culture is an important prerequisite for successful application of knowledge management and digital transformation, but at the same time, the application of these two concepts in the organization inevitably affects (directly or indirectly) and leads to certain changes in employee thinking and overall organizational culture.

The digital business transformation affects (sooner or later) all business processes enabling their implementation more efficient. This refers to the process of knowledge management, which is supported by digital technologies and based on the entire business digitalization, can reach great goals in terms of its importance for managing the organization and make it a crucial part of modern management system.

It is obvious that there is no successful digital business transformation without adequate knowledge management. Without efficient knowledge management, no one can expect the formation of the quantum of organizational knowledge that is necessary to clearly identify the reasons for initiating digital transformation, determine the elements of the organizational value chain that need to be transformed and determine priorities in digital transformation. Knowledge management has a crucial role in determining the context and way of realization of digital transformation.

\section{Conclusion}

Digital transformation is an inevitable step that all companies must take in order to survive in the market. Successful digital transformations start with a change in employee thinking, which further leads to a change in organizational culture. In contrast, companies that start their digital transformation by changing technology often fail. Companies need to learn how to do business in the digital world and how to invest the right resources in the right places. The fact is that digital 
transformation demands investing in digital technologies. Therefore, before starting the whole process of digital transformation, organizations must first assess, from different perspectives, which processes are currently hampering growth and which processes must be digitalized first. In this context, it is important to connect people who need this knowledge with people who have that knowledge. Therefore, it is necessary to manage knowledge in the organization in an optimal way. Only then the correct digitization process can be chosen. Digital transformation is an ongoing process. It involves creating and maintaining an environment in which people enjoy communicating and exchanging ideas. These processes promote the exchange of knowledge, which leads to cultural change, which is a necessary component of digital transformation and which should be the first step in the process of knowledge management and in the process of digital transformation.sm

\section{References}

Alavi, M., \& Leidner, D. (1999). Knowledge Management Systems: Issues, Challenges, and Benefits. Communications of the Association for Information Systems, 1(7), 1-37. https://doi.org/10.17705/1cais.00107

Alavi, M., \& Leidner, D. (2001). Knowledge Management and Knowledge Management Systems: Conceptual Foundations and Research Issues. MIS Quarterly Executive, 25(1), 107-136. https://doi.org/10.17705/1CAIS.00107

APQC. (2019, March). Knowledge Management Meets Digital Transformation. Retrieved July 19, 2020, from https://www.apqc.org/resource-library/resourcelisting/knowledge-management-meets-digitaltransformation.

Brereton, P., Kitchenham, B. A., Budgen, D., Turner, M., \& Khalil, M. (2007). Lessons from applying the systematic literature review process within the software engineering domain. Journal of Systems and Software, 80(4), 571-583. https://doi.org/10.1016/j.jss.2006.07.009

Choi, B., Poon, S. K., \& Davis, J. G. (2008). Effects of knowledge management strategy on organizational performance: A complementarity theory-based approach. Omega, 36(2), 235-251. https://doi.org/10.1016/j.omega.2006.06.007

Drechsler, K., Gregory, R., Wagner, H., \& Tumbas, S. (2020). At the Crossroads between Digital Innovation and Digital Transformation. Communications of the Association for Information Systems, 47, 51-69. https://doi.org/10.17705/1CAIS.04723

Halper, F. (2019). Driving Digital Transformation Using Al and Machine Learning. Renton: TDWI.

Helmy Ismail Abdelaal, M., Khater, M. \& Zaki, M. (2018). Digital Business Transformation and Strategy: What Do We Know So Far?. Cambridge: University of Cambridge.

https://doi.org/10.13140/RG.2.2.36492.62086
Jokanović, B., Tomić, I., \& Duđak, L. (2017). Uloga informacionih tehnologija u menadžmentu znanja. Paper presented at the annual meeting Trendovi razvoja: Položaj visokog obrazovanja i nauke u Srbiji, Zlatibor.

Kaljević, J. (2016). Primena informacionih tehnologija u fazi deljenja znanja u organizacijama. Zbornik Radova Univerziteta Sinergija, 16(1), 26-30. https://doi.org/10.7251/zrsng1501026k

Kane, G. (2019). The Technology Fallacy. Research Technology Management, 62(6), 44-49. https://doi.org/10.1080/08956308.2019.1661079

Kitchenham, B., Pearl Brereton, O., Budgen, D., Turner, M., Bailey, J., \& Linkman, S. (2009). Systematic literature reviews in software engineering - A systematic literature review. Information and Software Technology, 51(1), 715. https://doi.org/10.1016/j.infsof.2008.09.009

Kitchenham, B., Pretorius, R., Budgen, D., Brereton, O. P., Turner, M., Niazi, M., et al. (2010). Systematic literature reviews in software engineering - A tertiary study. Information and Software Technology, 52(8), 792-805. https://doi.org/10.1016/j.infsof.2010.03.006

Markić, M. (2016). Konceptualni model utjecaja upravljanja znanjem na organizacijske performanse. Mostariensia, 20(1-2), 185-197.

Mcinerney, C. R., \& Koenig, M. E. D. (2011). Knowledge Management (KM) Processes in Organizations: Theoretical Foundations and Practice. In Synthesis Lectures on Information Concepts, Retrieval, and Services, 3(1), 1-96. https://doi.org/10.2200/s00323ed1v01y201012icr018

Melão, N., \& Pidd, M. (2008). Business processes: Four perspectives. In V. Grover \& M. L. Markus (Eds.), Business Process Transformation (pp. 41-66). New York: Advances in Management Information Systems.

Mićić, L. (2016). Značaj informacionih sistema za upravljanje znanjem. Zbornik radova Nova naučna edukativna misao, 1, 15-25.

Nikolić, M., Vesić, T., \& Stošić-Mihajlović, L. (2017). Upravljanje znanjem, informacijama i organizacionim promenama. Trendovi u Poslovanju, 10(2), 19-27. https://doi.org/10.5937/trendpos1702019N

Paulin, D., \& Suneson, K. (2011). Knowledge Transfer, Knowledge Sharing and Knowledge Barriers - Three Blurry Terms in KM. Proceedings of the European Conference on Knowledge Management, ECKM, 2, 752-760.

Petrov, V., Ćelić, Đ., Uzelac, Z., \& Drašković, Z. (2020). Specific influence of knowledge intensive and capital intensive organizations on collaborative climate and knowledge sharing in SMEs. Strategic Management, 25(1), 3-11. https://doi.org/10.5937/StraMan2001003P

Pham, N.T., Phan, Q.P.T., Tučková, Z., Vo, N., \& Nguyen, L.H.L. (2018). Enhancing the organizational citizenship behavior for the environment: the roles of green training and organizational culture. Management \& Marketing, 13(4), 1174-1189. https://doi.org/10.2478/mmcks-2018-0030

Rašinović, B. (2018). Hijerarhija znanja i Earlova taksonomija upravljanja znanjem. Radovi Filozofskog Fakulteta u Sarajevu, 21(1), 208-228. 
Schumann, C. A., \& Tittmann, C. (2015). Digital business transformation in the context of knowledge management. Proceedings of the European Conference on Knowledge Management, ECKM, 671-675.

Sofronijević, A., Milićević, V., \& Ilić, B. (2017). Strategijski pristup digitalnoj transformaciji poslovanja. TehnikaMenadžment, 67(2), 273-279. https://doi.org/10.5937/tehnika1702273S

Tešić, B., Marković, M., Plećić, K., \& Pantelić, I. (2013). Menadžment znanjem i informacione tehnologije. Zbornik radova V Naučnog Skupa USPON, 198-205.

Uzelac, Z., Ćelić, Đ., Drašković, Z., Berić, D., \& Petrov, V. (2018). Deljenje znanja u malim i srednjim preduzećima u IT sektoru. Zbornik radova INFOTEH-JAHORINA, 250-254.

\section{$\triangle$ Correspondence}

\section{Tihomir Zoranović}

Faculty of Agriculture, University of Novi Sad

Trg Dositeja Obradovića 8, 21102, Novi Sad, Serbia

E-mail: tihomir.zoranovic@polj.uns.ac.rs
Vukotić, S., Zakić, N., \& Ćurčić, N. (2017). Menadžment znanja i upravljanje inovacijama kao izvor poslovnog uspeha i konkurentske prednosti preduzeća. Zbornik radova Politehnika, 436-442.

Zbuchea, A., \& Vidu, C.-M. (2018). Knowledge Management in the Digital Era. Strategica, 4(2), 696704. 